\title{
Pengaruh Konsentrasi Larutan Katalis dan Bentuk Elektroda dalam Proses Elektrolisis untuk Menghasilkan Gas Brown
}

\author{
Jumiati1), Joko Sampurno1), Irfana Diah Faryuni ${ }^{1)}$ \\ 1)Program Studi Fisika \\ 1) Fakultas Matematika dan Ilmu Pengetahuan Alam \\ Universitas Tanjungpura, Pontianak \\ Email : Miyza.swetnmoet@gmail.com
}

\begin{abstract}
Abstrak
Telah dibuat sebuah alat untuk menghasilkan gas brown menggunakan metode elektrolisis. Alat ini dibuat untuk mengetahui pengaruh bentuk elektroda dan konsentrasi katalis terhadap volume gas brown. Elektroda yang digunakan berbahan stainless steel, dengan variasi bentuk diantaranya lempeng, spiral, dan pipa silinder. Tegangan yang diberikan ke dalam larutan katalis $\mathrm{CaCl}_{2}$ (kalsium klorida) yang telah divariasikan (0,014 M, 0,023 M, 0,027 M, 0,032 M, 0,038 M) yaitu sebesar 9 V. Hasil penelitian selama 40 menit menunjukan bahwa volume terbesar penghasil gas brown terdapat pada elektroda pipa silinder dengan konsentrasi 0,038 M.
\end{abstract}

Kata Kunci : Gas Brown, Elektrolisis

\section{Pendahuluan}

Ketergantungan manusia terhadap energi fosil, misalnya energi untuk pembangkit listrik, industri dan berbagai macam alat-alat transportasi tidak dapat dipisahkan dalam upaya memenuhi kebutuhan kesehariannya. Meningkatnya jumlah penduduk dunia dari tahun ke tahun menyebabkan kebutuhan akan energi semakin besar, sedangkan jumlah energi yang tersedia hanya cukup untuk beberapa tahun mendatang. Konsumsi bahan bakar ini dapat berdampak negatif terhadap lingkungan. Melihat kondisi tersebut maka saat ini sangat diperlukan penelitian yang intensif untuk mencari, mengoptimalkan dan menggunakan sumber energi alternatif. Dewasa ini salah satu bentuk energi alternatif yang menjadi perhatian besar dari banyak negara maju adalah gas brown yang merupakan gabungan gas hidrogen dan oksigen. Suplai energi yang dihasilkan oleh gas brown sangat bersih karena hanya menghasilkan uap air sebagai emisi gas buang serta bahan bakunya berupa air yang merupakan sumber daya alam yang dapat diperbaharui serta kelimpahannya di alam cukup besar.

Penelitian berkenaan dengan gas brown telah dilakukan oleh beberapa para peneliti diantaranya: Tjatur, dkk (2009) yang membuat kompor air dengan 6 tabung elektrolizer menggunakan daya sebesar 202,4 volt. Aditya dan Andang (2011) memproduksi hidrogen dengan sistem elektrolisis suhu tinggi dan mampu menghasilkan hidrogen dalam skala besar dengan tingkat kemurnian tinggi. Putra (2010) memproduksi gas hidrogen dan gas oksigen dengan cara mengelektrolisis larutan $\mathrm{KOH}$ dan menyimpulkan bahwa, semakin besar konsentrasi larutan maka volume gas yang dihasilkan semakin besar. Suyuty (2011) membuat generator hidrogen penghasil gas brown dan mereduksi SOx-NOx dari motor diesel menggunakan elektroda stainless steel dan berhasil mendapatkan arus yang besar serta gas yang stabil dengan elektrolit air laut.

Berdasarkan latar belakang di atas, dalam penelitian ini dilakukan proses elektrolisis untuk menghasilkan gas brown dengan variasi bentuk elektroda dan konsentrasi larutan katalis yang diharapkan dapat berpengaruh terhadap kuantitas produksi gas brown.

\section{Landasan Teori}

Gas brown yang ditemukan oleh Yull Brown merupakan campuran gas hidrogenhidrogen-oksigen yang dihasilkan dari sistem elektrolisis (Farid, dkk, 2012).

Elektrolisis adalah suatu peristiwa yang terjadi ketika arus listrik dialirkan melalui senyawa ionik dan senyawa tersebut mengalami reaksi kimia (Brady, 2008). Menurut Tjatur, dkk (2009) pergerakan elektron pada proses elektolisis dapat terlihat pada Gambar 1.

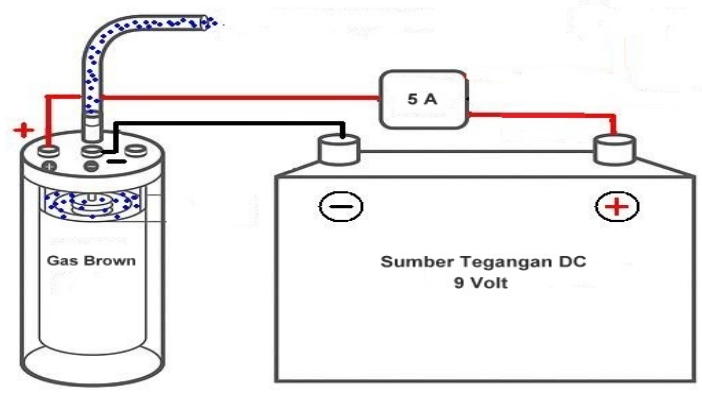

Gambar 1. Proses Elektrolisis

(http:/ / HHOSuperpack.com/ / HHOelectric) 
Persamaan kimia elektrolisa air sebagai berikut (Tjatur, dkk, 2009):

$$
\text { Energi (listrik) }+2 \mathrm{H}_{2} \mathrm{O}_{(\mathrm{l})} \rightarrow \mathrm{O}_{2(\mathrm{~g})}+2 \mathrm{H}_{2(\mathrm{~g})}
$$

Ketika energi listrik diberikan pada dua molekul air, maka air akan terurai menjadi unsur-unsur penyusun aslinya yaitu satu molekul oksigen dan dua molekul hidrogen. Pada proses ini molekul air terbagi menjadi ion hidrogen positif $\left(\mathrm{H}^{+}\right)$dan ion hidroksida $(\mathrm{OH})$ (Tjatur, dkk, 2009).

$$
\mathrm{H}_{2} \mathrm{O}_{(1)} \rightarrow \mathrm{H}^{+}+\mathrm{OH}^{-}
$$

$\mathrm{H}^{+}$merupakan proton yang bebas menangkap elektron ( $\mathrm{e}^{-}$) dari katoda, kemudian menjadi atom hidrogen biasa dan netral (Tjatur, dkk, 2009).

$$
\mathrm{H}^{+}+\mathrm{e}^{-} \rightarrow \mathrm{H}
$$

Atom hidrogen ini berkumpul dengan atom hidrogen lain dan membentuk molekul gas dalam bentuk gelembung kemudian naik ke permukaan (Tjatur, dkk, 2009).

$$
\mathrm{H}+\mathrm{H} \rightarrow \mathrm{H}_{2(\mathrm{~g})}
$$

Elektroda positif menyebabkan ion hidroksida $(\mathrm{OH})$ bergerak ke anoda. Ketika mencapai anoda, kelebihan elektron dilepas yang kemudian diambil oleh hidroksida dari atom hidrogen sebelumnya. Ion hidroksida bergabung dengan molekul hidroksida yang lain dan membentuk 1 molekul oksigen dan 2 molekul air (Tjatur, dkk, 2009):

$$
4 \mathrm{OH}^{-} \rightarrow \mathrm{O}_{2(\mathrm{~g})}+2 \mathrm{H}_{2} \mathrm{O}_{(\mathrm{l})}+4 \mathrm{e}^{-}
$$

Molekul oksigen yang dihasilkan dari proses ini sangat stabil, kemudian gelembungnya naik ke permukaan. Proses tersebut terjadi secara berulang, bergantung pada jenis kation dalam larutan. Jika kation berasal dari logam dengan potensial elektrode lebih kecil atau rendah maka air yang akan tereduksi.

Massa produk yang dihasilkan selama proses elektrolisis dikembangkan pertama kali oleh Michael Faraday (1791-1867). Hubungan antara muatan dan arus digambarkan oleh persamaan (6) sebagai berikut (Chang, 2004):

$$
q=I x t
$$

dimana q menyatakan muatan elektron (Coloumb), I menyatakan arus (Ampere), dan t menyatakan waktu (sekon).

Muatan listrik ditentukan oleh banyaknya mol elektron yang melewati rangkaian, yang diberikan oleh persamaan (7) sebagai berikut (Chang, 2004):

$$
\text { Muatan total }(\mathrm{q})=\mathrm{nF}
$$

Dimana $\mathrm{F}$ menyatakan kontanta Faraday (96.500 Coloumb ) dan $\mathrm{n}$ menyatakan jumlah $\mathrm{mol}$ (mol).

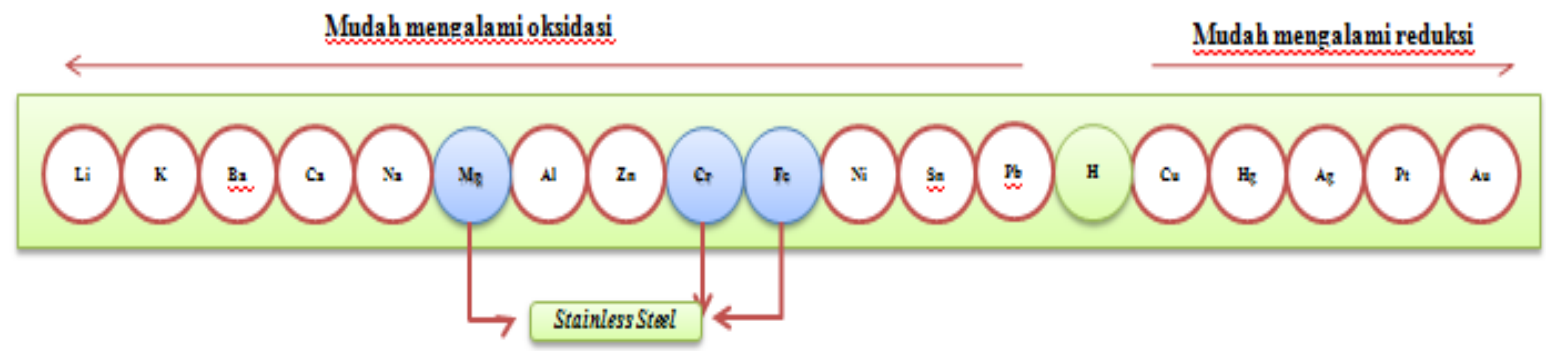

Gambar 2. Deret Volta (http:/ / herlinaidra.blogspot.com/ / deret-volta.html)

Suyuty (2011) merekomendasikan stainless steel sebagai elektroda pada hidrogen generator. Sehingga pada penelitian ini digunakan stainless steel sebagai elektroda pada elektrolit $\mathrm{CaCl}_{2}$, selain itu yang mendasari penggunaan elektroda ini karena kandungan. (Cr) yang besar sehingga dapat mencegah terjadinya proses korosi (pengkaratan logam). Rasio rapat arus terhadap kuat medan listrik disebut sebagai konduktivitas urutan logamlogam (ditambah hidrogen) berdasarkan kenaikan potensial elektroda standarnya dapat dilihat pada Gambar 2.

\section{Metodologi}

Penelitian ini dimulai dengan mempersiapkan padatan $\mathrm{CaCl}_{2}$ (kalsium klorida), akuades dan labu ukur $1000 \mathrm{~mL}$, selanjutnya membuat larutan katalis $\mathrm{CaCl}_{2}$ dengan konsentrasi 0,014 M, 0,023 M, 0,027 M, 0,032 M, dan 0,038 $\mathrm{M}$ yang telah dilarutkan menggunakan air akuades. Larutan tersebut dimasukan ke dalam reaktor kemudian ditutup menggunakan akrilik yang telah terpasang 
elektroda (spiral, lempeng, atau pipa silindera). Ruang kosong yang berada dalam reaktor disedot menggunakan pompa vakum agar gas yang terbentuk tidak tercampur oleh gas oksigen dari luar dan gas yang dihasilkan hanya berasal dari proses elektrolisis. Setelah itu elektroda yang berada di dalam reaktor dihubungkan ke sumber tegangan DC 9 Volt. Proses elektrolisis dimulai selama 40 menit dan gas yang telah dihasilkan dihubungkan ke tempat pendinginan gas, hal ini bertujuan untuk menghindari terjadinya fluktuasi gas yang berlebihan kemudian gas dihubungkan ke manometer tabung U. Data-data hasil pengamatan diambil setiap 5 menit diantaranya ketinggian kolom air pada kolom $1\left(\mathrm{~h}_{1}\right)$ dan kolom $2\left(\mathrm{~h}_{2}\right)$ diambil dengan cara membuka klep, kuat arus (I) yang terbaca pada amperemeter, serta suhu (T) pada termometer. Setelah proses elektrolisis selesai kemudian reaktor dikuras dan digunakan pompa vakum untuk mengkondisikan reaktor agar gas sisa hasil proses elektrolisis sebelumnya tidak tercampur dengan hasil elektrolisis selanjutnya. Proses diulangi untuk setiap konsentrasi yang sama diulangi pada bentuk elektroda yang berbeda.

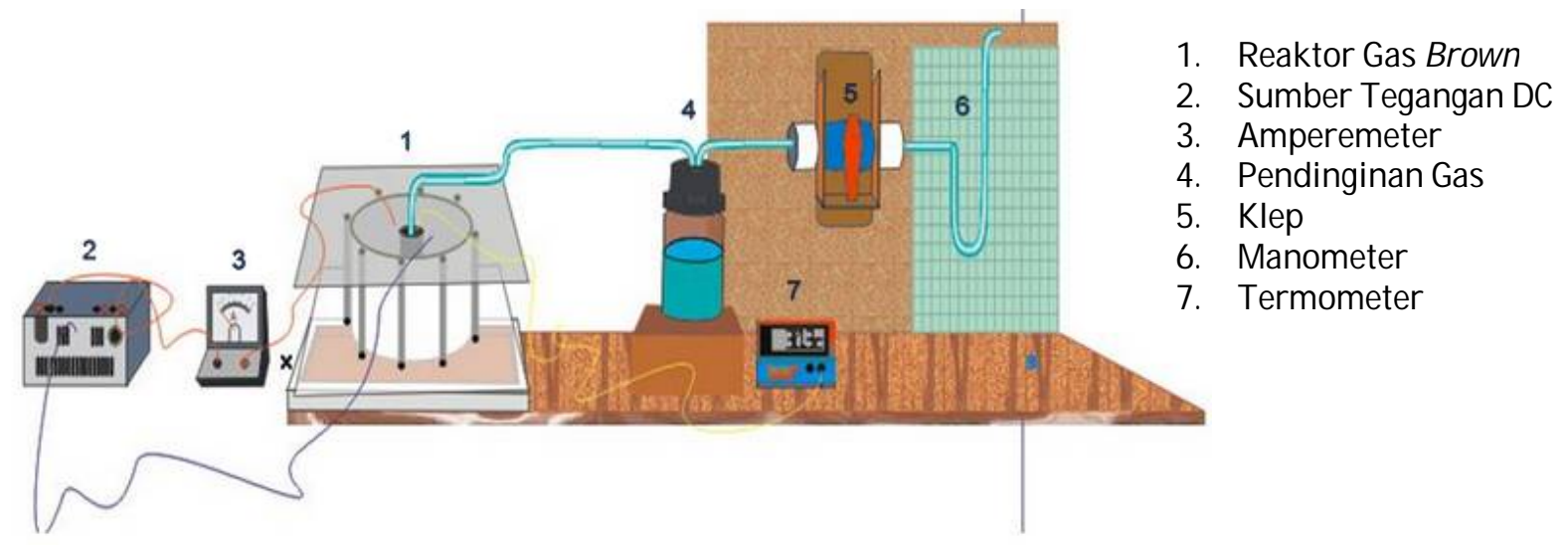

Gambar 3. Desain Sistem Instalansi Gas Brown

\section{Hasil dan Pembahasan}

Gambar 5(a) s.d Gambar 5(e) menunjukan adanya kenaikan volume secara linear terhadap waktu. Hal ini menunjukan semakin lama waktu elektrolisis elektron-elektron yang terbentuk semakin banyak dan padat sehingga mempermudah transfer elektron dari larutan ke elektroda. Elektroda pipa silinder menghasilkan volume yang paling besar, karena arus yang dihasilkan lebih besar, besarnya arus sebanding dengan jumlah muatan elektron dalam larutan. Semakin besar arus maka muatan elektron yang terbentuk semakin banyak dan padat sehingga lebih cepat mencapai elektroda.

Hubungan konsentrasi larutan katalis terhadap volume gas brown yang telah dielektrolisis selama 40 menit dapat dilihat pada Gambar 4. Gambar tersebut menunjukan produksi gas brown tidak mengalami kenaikan yang linear terhadap penambahan konsentrasi larutan kalsium klorida. Elektroda spiral pada konsentrasi 0,038 menghasilkan volume yang besarnya sama dengan konsentrasi sebelumnya. Hal ini disebabkan arus yang terbaca pada amperemeter sama, sehingga jumlah muatan elektron yang mengalir selama proses elektrolisis juga sama. Elektroda lempeng pada konsentrasi 0,032 M mengalami penurunan volume. Hal ini diduga disebabkan oleh katalis yang digunakan yaitu $\mathrm{CaCl}_{2}$.

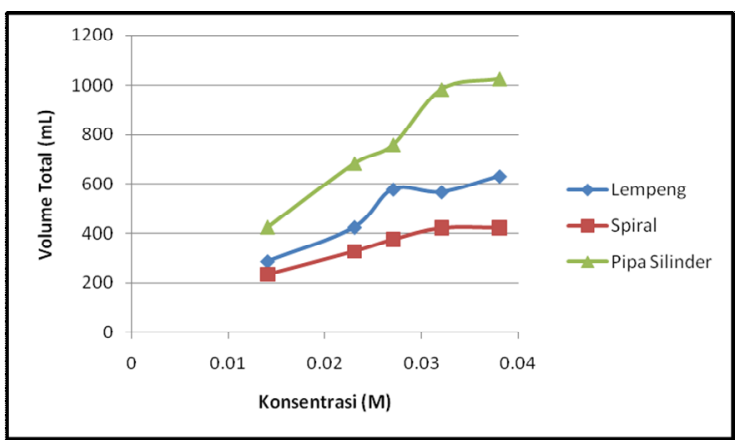

Gambar 4. Volume Gas Vs Konsentrasi Larutan Selama 40 Menit

Semakin besar konsentrasi larutan kalsium klorida, maka endapan yang terbentuk selama proses elektrolisis semakin besar. Hal tersebut menyebabkan terhalangnya proses pembentukan gelembung gas pada elektroda. Elektroda pipa silinder mengalami penurunan volume pada konsentrasi 0,027 M yang disebabkan endapan yang terbentuk selama proses elektrolisis tidak dapat melepaskan diri dari elektroda. Namun elektroda ini penghasil gas brown terbesar pada setiap konsentrasi. Hal 
ini disebabkan arus yang terbaca pada amperemeter lebih besar dari elektroda lempeng dan spiral. Sehingga menyebabkan ion-ion yang banyak membantu dalam mempercepat transfer elektron dari larutan ke elektroda. Berdasarkan uji Anova pada pengambilan keputusan dengan $\mathrm{H}_{0}$ : ketiga varians populasi adalah sama dan $\mathrm{H}_{1}$ : ketiga varians populasi adalah tidak sama. Dengan menggunakan tingkat kepercayaan 0,05 didapat nilai $\mathrm{F}_{\text {tabel }} 3,467$. Tolak $\mathrm{H}_{0}$ dan terima $\mathrm{H}_{1}$ jika rasio uji lebih besar dari $F_{\text {tabel. }}$. Dengan uji Anova tersebut dapat dilihat perbedaan volume gas untuk setiap bentuk elektroda terhadap

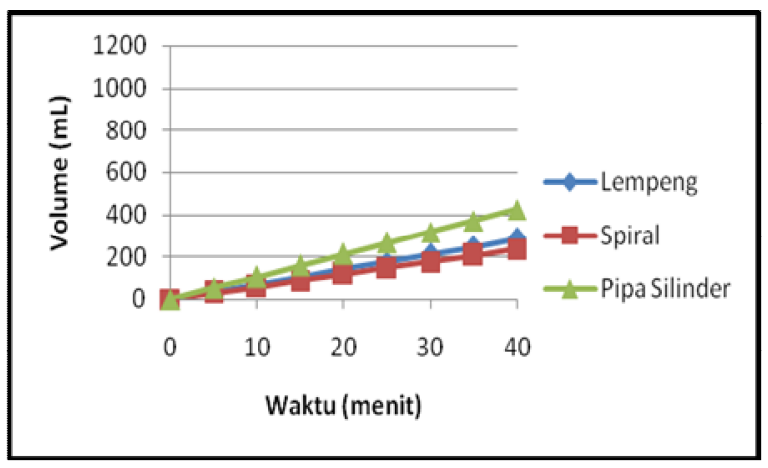

(a)

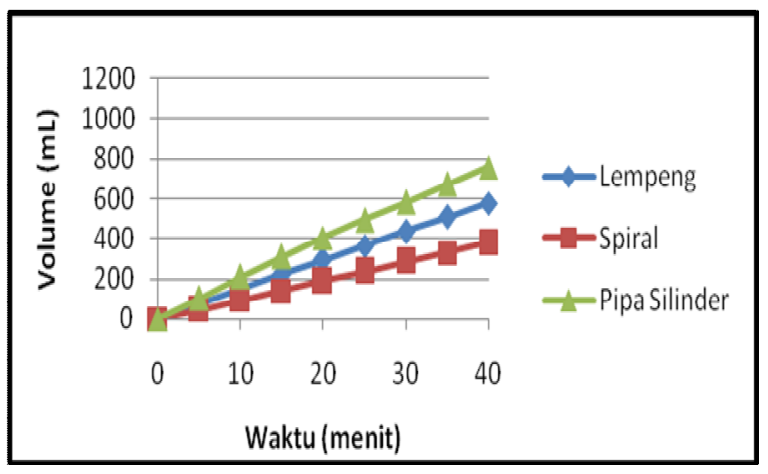

(c) konsentrasi masing-masing. Konsentrasi 0,014 M, 0,023 M, 0,027 M, 0,032 M, dan 0,038 M dengan nilai rasio uji berurut-urut 2,437, 3,810, 3,332, 5,417, dan 5,642. Dapat terlihat dari nilai rasio uji, semakin besar konsentrasi larutan nilai rasio uji semakin besar. Kecuali untuk konsentrasi 0,014 $\mathrm{M}$ dan 0,027 $\mathrm{M}$ dengan nilai rasio uji lebih kecil dari $\mathrm{F}_{\text {tabel }}$ maka $\mathrm{H}_{0}$ diterima. Dapat disimpulkan, berdasarkan uji Anova dengan mengambil nilai rasio uji terbesar maka dari ketiga bentuk elektroda yaitu lempeng, spiral, dan pipa silinder pada konsentrasi 0,038 M terdapat perbedaan volume gas diantara ketiganya.

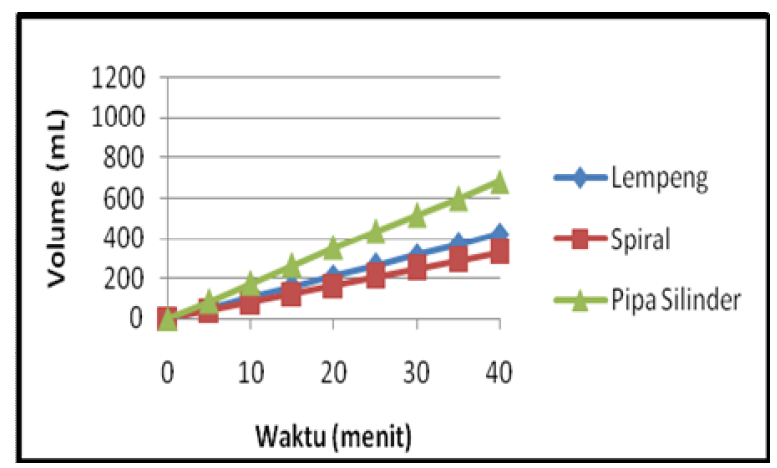

(b)

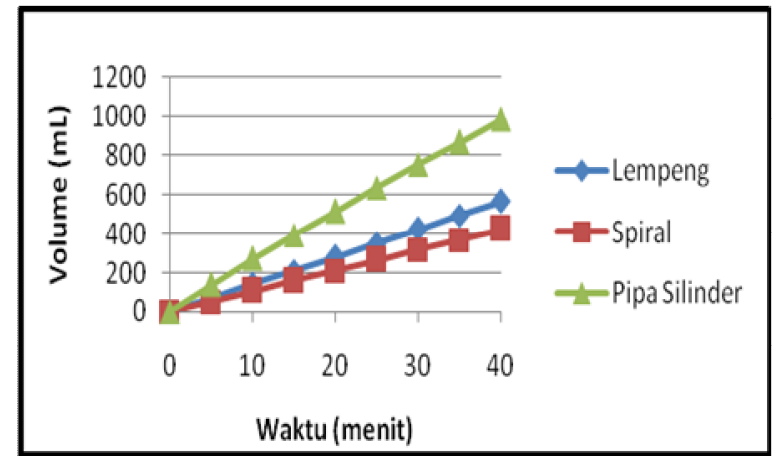

(d)

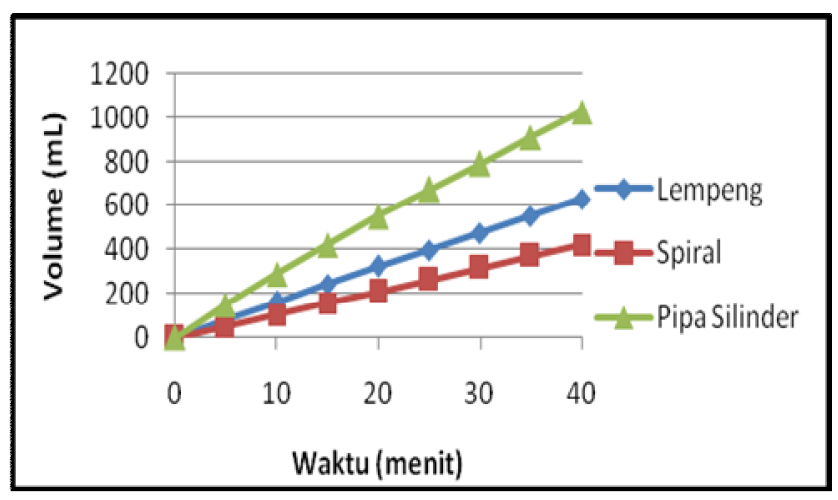

(e)

Gambar 5. Volume Terhadap Waktu pada Konsentrasi (a) 0,014 M, (b) 0,023M, (c) 0,027 M, (d) 0,032 M, dan (e) $0,038 \mathrm{M}$ 
Menurut Rahayu (1995) reaksi elektrolisis termasuk dalam reaksi heterogen, karena reaksinya berlangsung pada elektroda, tanpa elektroda reaksi ini tidak akan berlangsung. Dalam reaksi ada dua tahap penentu laju reaksi yaitu adsorbsi pereaksi di permukaan dan reaksi pada permukaan. Ketika reaksi adsorbsi pereaksi di permukaan terjadi kesetimbangan antara larutan homogen dengan sistem permukaan elektroda sehingga konsentrasi pereaksi mengalami konversi dari mol per volume menjadi mol per $\mathrm{cm}^{2}$. Sedangkan pada reaksi permukaan posisi pereaksi yang teradsobsi harus berdekatan (berdampingan) sehingga reaksi dapat terjadi.

Elektroda pada penelitian ini divariasikan bentuknya menjadi lempeng, spiral, dan pipa silinder dengan bahan stainless steel yang memiliki dua sisi yang berbeda (mengkilap dan tidak). Stainless steel merupakan elektroda aktif, dimana mereka akan ikut bereaksi selama proses elektrolisis berlangsung. Oleh sebab itu, lama kelamaan elektroda ini akan mengalami penurunan aktivitasnya. Ini berarti bahwa kemampuan untuk mempercepat reaksi tertentu telah berkurang. Hal ini terbukti, semakin lama elektroda digunakan kemampuan menghasilkan gas semakin rendah, karena permukaan elektroda semakin lama semakin berubah warna dan perlahan tergerus. Elektroda spiral mengalami perubahan yang lebih cepat dari bentuk elektroda lempeng dan pipa silinder, karena pada elektroda spiral suhu yang terbentuk pada konsentrasi yang sama lebih cepat meningkat dari pada elektroda yang lain. Kerja yang dilakukan elektroda spiral lebih besar, sehingga permukaan elektroda lebih cepat mengalami perubahan warna pada bagian anoda.
Berdasarkan data-data yang telah dibahas sebelumnya dapat diketahui bahwa elektroda pipa silinder lebih banyak menghasilkan gas brown daripada bentuk spiral dan lempeng. Hal ini disebabkan oleh jarak antar elektroda. Secara teori, luas permukaan yang sama akan menghasilkan volume gas yang sama karena adsorbsi pereaksi di permukaan mengalami kesetimbangan yang sama pada konversi mol per vol menjadi mol per $\mathrm{cm}^{2}$, dengan luasan yang sama distribusi pereaksi di permukaan juga sama. Tetapi jarak antar elektroda mempengaruhi proses transfer elektron, semakin dekat jarak antar elektroda maka besar hambatan pergerakan elektron bernilai kecil begitu pula sebaliknya. Elektroda spiral memiliki jarak elektroda yang lebih kecil dari elektroda pipa silinder. Akan tetapi elektroda pipa silinder menghasilkan volume yang lebih besar. Hal ini disebabkan posisi pereaksi pada permukaan, dengan bentuk spiral posisi pereaksi yang teradsobsi pada permukaan tidak sejajar atau tidak banyak yang berdampingan, sehingga hal tersebut menyebabkan tidak banyak gas yang terbentuk karena reaksi tidak dapat berlangsung. Pada proses elektrolisis, suhu mengalami peningkatan selama selang waktu tertentu. Peningkatan suhu mengakibatkan energi molekul-molekul meningkat, yang menyebabkan molekulmolekul bergerak lebih cepat. Hal ini mengakibatkan banyak molekul yang mencapai energi pengaktifan sehingga reaksi berlangsung lebih cepat. Peningkatan suhu mempengaruhi produksi gas brown. Semakin meningkat suhu menyebabkan volume yang dihasilkan tiap waktu juga meningkat.

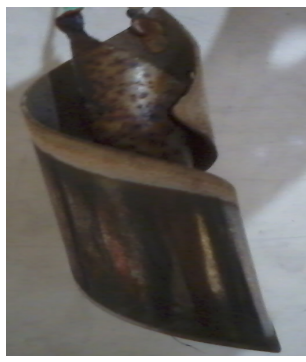

(a)

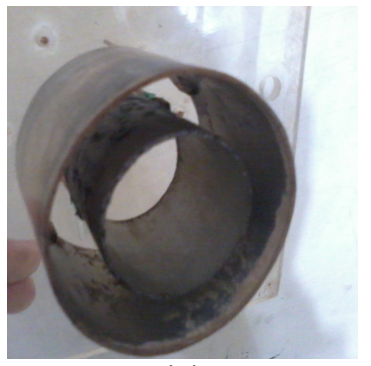

(b)

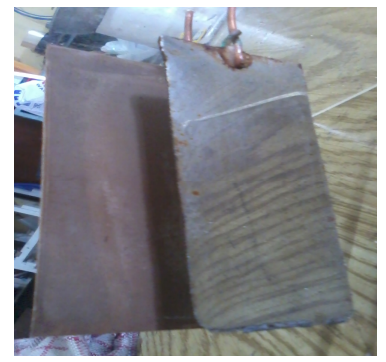

(c)

Gambar 6. (a) Elektroda Spiral, (b) Elektroda Pipa Silinder, (c) Elektroda Lempeng

\section{Kesimpulan}

Berdasarkan hasil penelitian yang telah dilakukan, dapat ditarik kesimpulan bahwa desain terbaik penghasil gas brown dari bentuk elektroda lempeng, spiral dan pipa silinder adalah menggunakan elektroda pipa silinder dan konsentrasi terbaik dari variasi konsentrasi katalis $\mathrm{CaCl}_{2}$ sebesar 0,014 M, 0,023 M, 0,027 M, $0,032 \mathrm{M}$ dan 0,038 Madalah konsentrasi katalis $\mathrm{CaCl}_{2}$ sebesar 0,038 M. 


\section{Daftar Pustaka}

Aditya, Muhammad dan Andang Widi Harto, 2011, Pengaruh Variasi Masukan Rapat Arus Listrik Menggunakan Molten Salt Reactor (Msr) terhadap Nilai Efisiensi Produksi Hidrogen dengan Sistem Elektrolisis Air Suhu Tinggi, Prosiding Seminar Nasional ke-17 Teknologi dan Keselamatan PLTN Serta Fasilitas Nuklir, Yogyakarta.

Brady, J.E., 2008, Kimia Universitas Asas dan Struktur, Binarupa Aksara, Jakarta.

Chang, Raymond, 2004, Kimia Dasar, Alih Bahasa: Suminar Setiati Achmadi, Ph.D, Erlangga, Jakarta.

Farid M. R. R., Totok Soehartanto, dan Suprapto, 2012, Perancangan dan Pembuatan Alat Pemproduksi Gas Brown dengan Metode Elektrolisis Berskala Laboratorium, JURNAL TEKNIK POMITS Vol. 1, No. 1, (2012) 1-4, Surabaya.

Giancoli, C, Doglas, 2001, Fisika, Alih Bahasa: Dra. Yuhilza Hanum, M. Eng, Erlangga, Jakarta.

Harinaldi, 2005, Prinsip-prinsip Statistik untuk Teknik dan Sains, Erlangga, Jakarta.

http:/ / Herinaldi.blogspot.com/ 2013/ 05/ 29/ De ret-Volta.

http:/ / HHOsuperpack.com/ 2014/ 02/ 13/ HHOelectric.

Kartono, 2009, Pengaruh Ukuran Ion Elektrolit terhadap Produksi Gas Hidrogen pada Elektrolisis Larutan Garam Klorida, Tugas Akhir Magister Pengajaran Kimia di Program Studi Kimia FMIPA-ITB, Bandung.

Putra, Arbie Marwan, 2010, Analisa Produktifitas Gas Hidrogen dan Gas Oksigen pada Elektrolisis Larutan KOH, Jurnal Neutron, Vol. 2, No.2, Fisika UIN Maulana Malik Ibrahim, Malang.

Rahayu, Susanto Imam, 1995, Kinetika Kimia, Penerbit ITB, Bandung.

Rivai, Harrizul, 1995, Asas Pemeriksaan Kimia, UI-Press, Jakarta.

Sebastian, otto., dan Tulus, B. S., 2013, Analisa Efisiensi Elektrolisis Air dari Hydrofill pada Sel Bahan Bakar, Jurnal Dinamis,Vol. II, No.12, Januari 2013, Teknik MesinUniversitas Surabaya, Surabaya.

Suyuty, Achmad, 2011, Studi Eksperimen Konfigurasi Komponen Sel Elektrolisis untuk Memaksimalkan pH Larutan dan Gas Hasil Elektrolisis dalam Rangka Peningkatan Performa dan Reduksi SOx NOx Motor Diesel, Surabaya.
Tjatur, Rusminto W., Nurhayati, dan Supa'at, 2009, Proses Elektrolisa pada Prototipe "Kompor Air" dengan Pengaturan Arus dan Temperatur, Politeknik Elektronika Negeri Surabaya-ITS, Surabaya. 